\title{
JOURNAL.RU
}

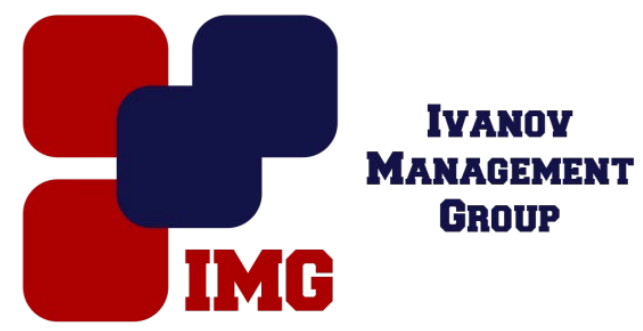

Жукова С.А., Морев М.И. ОГУ Оренбург, Россия

doi: 10.18411/lj-30-11-2016-2-05

idsp 000001:lj-30-11-2016-2-05

\section{Экопарковки как перспективный вариант решения транспортных и экологических проблем}

\section{Аннотация}

В данной статье представлены наиболее перспективные варианты решения парковочной проблемы в России. Подробно раскрыт один из представленных вариантов.

Ключевые слова: прирост автомобилей, нехватка парковочных мест, варианты решения, экопарковка.

Парковки в крупных городах России давно стали больной темой не только для автомобилистов, но и для чиновников разного уровня. Автомобилей становится все больше не только в мегаполисах, но и в небольших городах страны, а мест для парковки больше не становится - темпы решения проблемы в несколько раз отстают от скорости прироста транспорта у горожан.

Нехватка парковочных мест влечет за собой множество других проблем: искусственное сужение проезжей части из-за многометровых рядов припаркованных автомобилей, ухудшение экологической обстановки, порча газонов и многое другое. Но решение есть - и не одно.

Варианты решения:

- строительство подземных парковок;

- строительство многоярусных парковок;

- строительство перехватывающих парковок на въезде в город или его центральную часть;

- запрет или ограничение въезда в центр города на личном транспорте (кроме жителей центральных районов);

- увеличение штрафов за нарушение правил парковки; 
- создание экологических парковок. Это самый перспективный вариант решения парковочной проблемы - о нем хотелось бы сказать несколько слов.

Многие европейские страны уже несколько лет активно пользуются технологией строительства экологических парковок на газонах. Такой паркинг представляет собой обычный зеленый газон в городской черте, на котором без ущерба естественному травяному слою допускается остановка легкового транспорта.

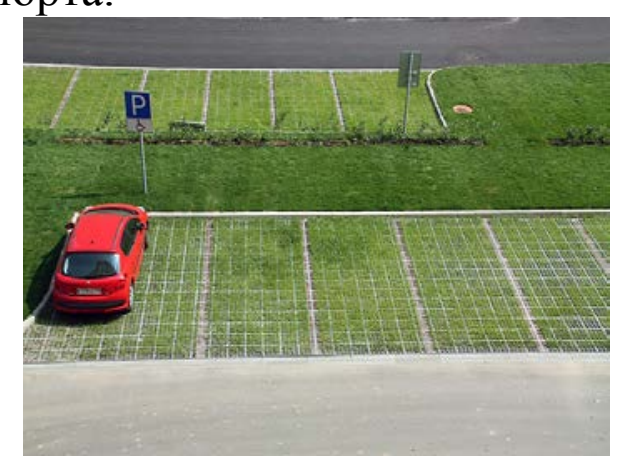

Pис.1 (экопарковка)

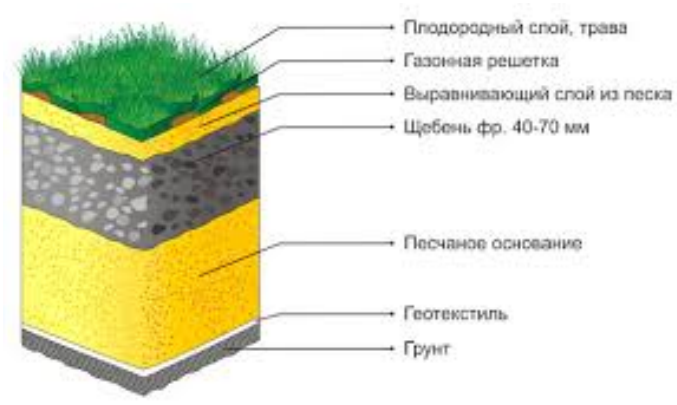

Рис.2 (конструктивные слои сооружения экопарковки)

Опыт Европы постепенно перенимают российские мегаполисы экопарковки по технологии функционального озеленения уже появились в некоторых районах Москвы, Санкт-Петербурга.

Технология строительства экологических парковок основана на каркасной защите корней растительного слоя газона - в основании парковочной площадки лежит специальная пластиковая конструкция ячеистой структуры, принимающая на себя всю нагрузку от веса припаркованных автомобилей. Такие специальные газонные решетки практически не заметны в траве - тонкие пластиковые стенки углублены в грунт, и на поверхности газона будут видны только в холодное время года.

На участок будущего паркинга укладывается газонная решетка и, при необходимости, геотекстиль (нетканое полотно из полимерных волокон).В ячейки закрепленной решетки насыпается грунт с семенами многолетних трав.Когда трава прорастает, парковка покрывается густым слоем естественной зелени.

В отличие от всех других вариантов решения проблемы с парковками - это самый экологичный, функциональный и эстетичный способ благоустройства любой территории. 


\section{Литература}

1. Бабков В.Ф., Андреев О.В., «Проектирование автомобильных дорог в 2-х частях» Ч.1-И учебник для вузов- Издание 2-е, переработанное и дополненное-,М,: Транспорт, 1987-368 с.

2. Карташкова Л.М., Штерн В.О. Проектирование автомобильных дорог: учебное пособие. Оренбург: ИНК ГОУ ОГУ, 2006. - 136 с.

3. Васильев, А.П. Справочная энциклопедия дорожника/ А.П. Васильев. -М.: Ви АртПлюс, 2005. - 647c. 